Article

\title{
Multimodal Counseling Interventions: Effect on Human Papilloma Virus Vaccination Acceptance
}

\author{
Oroma Nwanodi ${ }^{1, *}$ (D), Helen Salisbury ${ }^{2}$ and Curtis Bay ${ }^{3}$ \\ Obstetrics and Gynecology Locum Tenens, Salinas, CA 93902, USA \\ College of Graduate Health Studies, A. T. Still University, Mesa, AZ 85206, USA; hsalisbury@atsu.edu \\ 3 Department of Interdisciplinary Sciences, A. T. Still University, Mesa, AZ 85026, USA; cbay@atsu.edu \\ * Correspondence: o.nwanodi@juno.com; Tel.: +1-314-304-2946 \\ Academic Editor: Sampath Parthasarathy \\ Received: 10 October 2017; Accepted: 29 October 2017; Published: 6 November 2017
}

\begin{abstract}
Human papilloma virus (HPV) vaccine was developed to reduce HPV-attributable cancers, external genital warts (EGW), and recurrent respiratory papillomatosis. Adolescent HPV vaccination series completion rates are less than $40 \%$ in the United States of America, but up to $80 \%$ in Australia and the United Kingdom. Population-based herd immunity requires $80 \%$ or greater vaccination series completion rates. Pro-vaccination counseling facilitates increased vaccination rates. Multimodal counseling interventions may increase HPV vaccination series non-completers' HPV-attributable disease knowledge and HPV-attributable disease prophylaxis (vaccination) acceptance over a brief 14-sentence counseling intervention. An online, 4-group, randomized controlled trial, with 260 or more participants per group, found that parents were more likely to accept HPV vaccination offers for their children than were childless young adults for themselves (68.2\% and 52.9\%). A combined audiovisual and patient health education handout (PHEH) intervention raised knowledge of HPV vaccination purpose, $p=0.02$, and HPV vaccination acceptance for seven items, $p<0.001$ to $p=0.023$. The audiovisual intervention increased HPV vaccination acceptance for five items, $p<0.001$ to $p=0.006$. That HPV causes EGW, and that HPV vaccination prevents HPV-attributable diseases were better conveyed by the combined audiovisual and PHEH than the control 14-sentence counseling intervention alone.
\end{abstract}

Keywords: cervical cancer; counseling; human papilloma virus (HPV); HPV counseling; HPV-attributable diseases; HPV knowledge; HPV prophylaxis; HPV vaccination; HPV vaccination acceptance

\section{Introduction}

In the United States (U.S.), approximately 26,900 cases of high-risk human papilloma virus (HPV)-attributed genital and oropharyngeal cancers occur annually [1]. Overall, there are 38,793 HPV-attributed cancers annually in the U.S., an incidence of 11.7 per 100,000 persons [2]. High-risk oncogenic HPV types 16, 18, 31, 33, 45, 52, and 58 are associated with 92\% of HPV-attributable cancers [2]. Low-risk non-oncogenic HPV types 6 and 11 are responsible for $96-100 \%$ of external genital warts (EGW) that have an incidence of 205 persons per 100,000 persons, affecting up to one million Americans annually [3-5]. Low-risk, non-oncogenic HPV Types 6 and 11 also cause 0.43 to 4.3 cases of recurrent respiratory papillomatosis (RRP) per 100,000 children, and 1.8 cases of RRP per 100,000 adults [6,7]. The prevalence of high-risk oncogenic HPV ranges from 16.6 to $65.3 \%$, in American men ages 18 to 44 and American women ages 18 to 35, while low-risk non-oncogenic HPV prevalence ranges from 13.5 to $25.3 \%$ [3,8]. All told, this amounts to $75 \%$ of Americans experiencing an HPV infection once in their life [9]. 
The U.S. spent at least $\$ 700$ million in 2009 on HPV-attributable diseases [10]. Global approval of HPV vaccines began in 2006. The quadrivalent and nonavalent HPV vaccines (4vHPV and 9vHPV) prevent HPV-attributed cervical cancer, EGW, and RRP [4,7,11]. 4vHPV provides immunity from HPV-6, -11, -16, and -18. 9vHPV also provides immunity from HPV-31, -33, -45, -52, and -58 [2].

In 2009, a school-based 65\% 3-dose HPV vaccination rate for Australian females ages 12-26, reduced the incidence of female and male EGW by 16.7 and 20 percentage-points respectively [12]. Subsequently, Australia achieved a 79\% vaccination rate [13-15]. Higher school-based 3-dose HPV vaccination rates are $85 \%$ in Brazil and $81 \%$ in Britain $[14,15]$. In pre-HPV vaccination approval China, parental HPV vaccine acceptance was $36.2 \%$ [16]. France, like the U.S. lacks a national HPV vaccination program [13]. France had a 38\% adolescent female HPV vaccination series completion rate in 2013 [13]. This is closer to the U.S.' primarily clinic-based 32\% female 3-dose HPV vaccination rate, than that obtained by school-based vaccination programs worldwide [17]. Adolescent girls (13-17 years old) in the U.S. fared slightly better with a $40 \%$ vaccination rate in 2014 [9,18]. Conversely, adolescent boys in the U.S. fared worse with a $22 \%$ vaccination rate $[9,18,19]$. Underlying the importance of high HPV series vaccination rates, states with 3-dose adolescent female HPV vaccination rates of less than 33.9\% in 2013 are associated with moderate and high age-adjusted cervical cancer incidence, 6.76 to 9.75 per 100,000 [20].

Parental HPV-vaccination acceptance may be most strongly associated with attitude, habit, intention, and subjective norms, providing direction for vaccination education [21]. Media campaigns targeted to the Latino population led to a $15 \%$ increase in immunizations in California [22]. A Vietnamese language media-led information and education campaign in Texas achieved a 21.5 percentage-point increased awareness of Hepatitis B, a 31.9 percentage-point increase in awareness of free childhood vaccinations, and a 14 percentage-point increase in awareness that Hepatitis B is sexually transmitted [23]. The Guildford County North Carolina HPV Campaign presentation to healthcare staff, parents, and school staff increased parents' post-intervention knowledge of HPV-attributable disease by $31 \%$ [24]. After the presentation, $97 \%$ of Guilford County, North Carolina parents were supportive of a school-based HPV vaccination clinic [24]. Given that electronic-based HPV vaccine education can be $23 \%$ more costly than print-based HPV vaccine education, educational method relative effectiveness is important [25].

Public education can address adverse events of vaccines in general, the HPV vaccine specifically, and refute the assumption that HPV vaccination results in rebound increased sexual activity [26]. Public education can also address the epidemiology of HPV-attributed infections, susceptibility to HPV-attributed infections, and societal burden thereof, leading to HPV vaccination recommendation. As 19\% of parents are unsupportive of HPV vaccination, unless all other eligible children receive HPV vaccination, the U.S. cannot achieve an $80 \%$ or greater HPV vaccination completion rate for grade-school age children, necessary for herd immunity $[9,27]$. Attainment of HPV herd immunity protecting the un-vaccinated would reduce HPV-attributed disease in the U.S. If counseling interventions can steer parents who initially would not accept HPV vaccination to accept HPV vaccination, an $80 \%$ or greater HPV vaccination completion rate is achievable. The objective of this quantitative comparative study was to evaluate whether multimodal counseling interventions increased HPV vaccination series non-completers' knowledge of HPV-attributable disease and acceptance of HPV-attributable disease prophylaxis (vaccination), over a control 14-sentence counseling intervention.

\section{Materials and Methods}

We performed a single-blind, quantitative, four group, probability sampling, simple randomized, pre-test/post-test online survey (Figure 1) with a minimum of 260 participants per study group, comprised half of young adults and half of parents, about 60:40 female to male ratio, totaling 1109 participants overall (Figures 1 and 2, and Table 1). Response tracking for partial and complete respondents was used. Invitation tracking for unopened or bounced (undeliverable) online invitation accounting was not used. All participants completed an online 25-item demographic questionnaire including initial screening items (Questionnaire S1-S4). All four groups responded to the pre-test 49-item HPV 
Knowledge and Acceptance survey, completed their assigned independent variable, and completed the post-test 49-item HPV Knowledge and Acceptance survey. All questionnaires had a young adult version and a parent version (Questionnaires S2 and S3). Quantitative analysis of survey items 1-25, from pre- and post-tests of all four groups, formed this study. Prior to data collection, this study received an exempt status from the A. T. Still University Institutional Review Board (Permission S1).

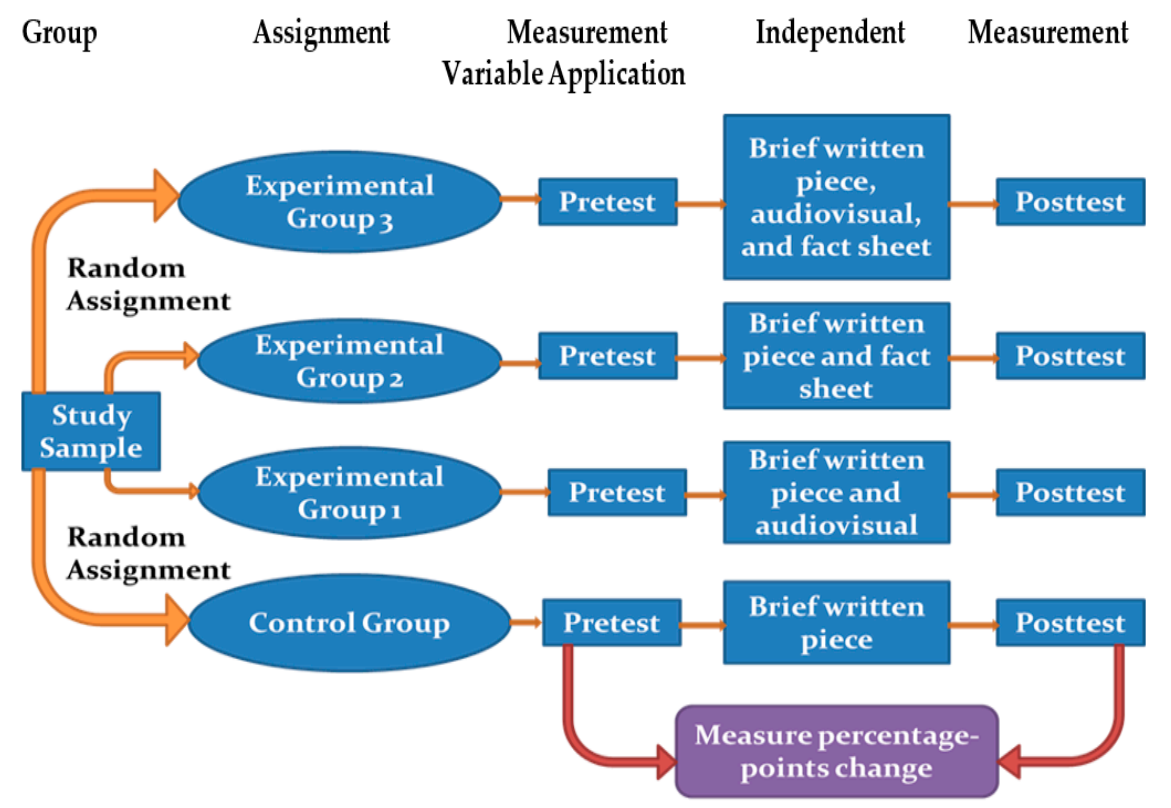

Figure 1. Study design flowchart. A single-blind, quantitative, four group, simple randomized, repeated measures, pre-test/post-test design with sample of young adults and parents from total survey respondents.

The first and control level counseling intervention received by all study groups was a 14-sentence informational brief, provided as Intervention S1 [28]. The second level counseling intervention comprised the 14-sentence informational brief and a 4.34-min audiovisual Why vaccinate against $H P V$ [29]. The third level counseling intervention was the 14-sentence informational brief and a public health education handout (PHEH) based on the Public Health Fact Sheet: Patient information about HPV and the HPV vaccine (Intervention S2) [30]. The fourth level counseling intervention comprised the 14-sentence informational brief, the audiovisual, and the PHEH. Consents were obtained for all independent variable use (Permissions S2-S4). The HPV Knowledge and HPV Vaccination Acceptance survey, comprised of the Parental HPV Survey, validated for use with 5-point Likert scale coded responses with Cronbach's alphas $>0.95$, a validated 3-item HPV acceptance questionnaire, both available without express consent for educational purposes, and a consented adaptation of focused interview questions [26-28].

In February 2015, SurveyMonkey Audience invited Americans 19 years and older to participate via age-based probability sampling with simple randomization to groups. SurveyMonkey Audience protocol determined the participation incentive. Eligible participants were age 19 or older, able to read and accept an online Survey Participation Consent in English, able to complete the online survey in English, and had not completed the HPV vaccination series. Young adults, age 19-26 years could participate offering opinions for themselves without regard to any child(ren) they may have. Young adults could not also participate as parents. Interested persons progressed to the inclusion/exclusion criteria items. Consent was implied once a potential participant proceeded to the survey instrument screen. Of 2312 initial respondents, 1470 were eligible, and 1109 eligible participants (75.4\%) completed the survey (Figure 2). 


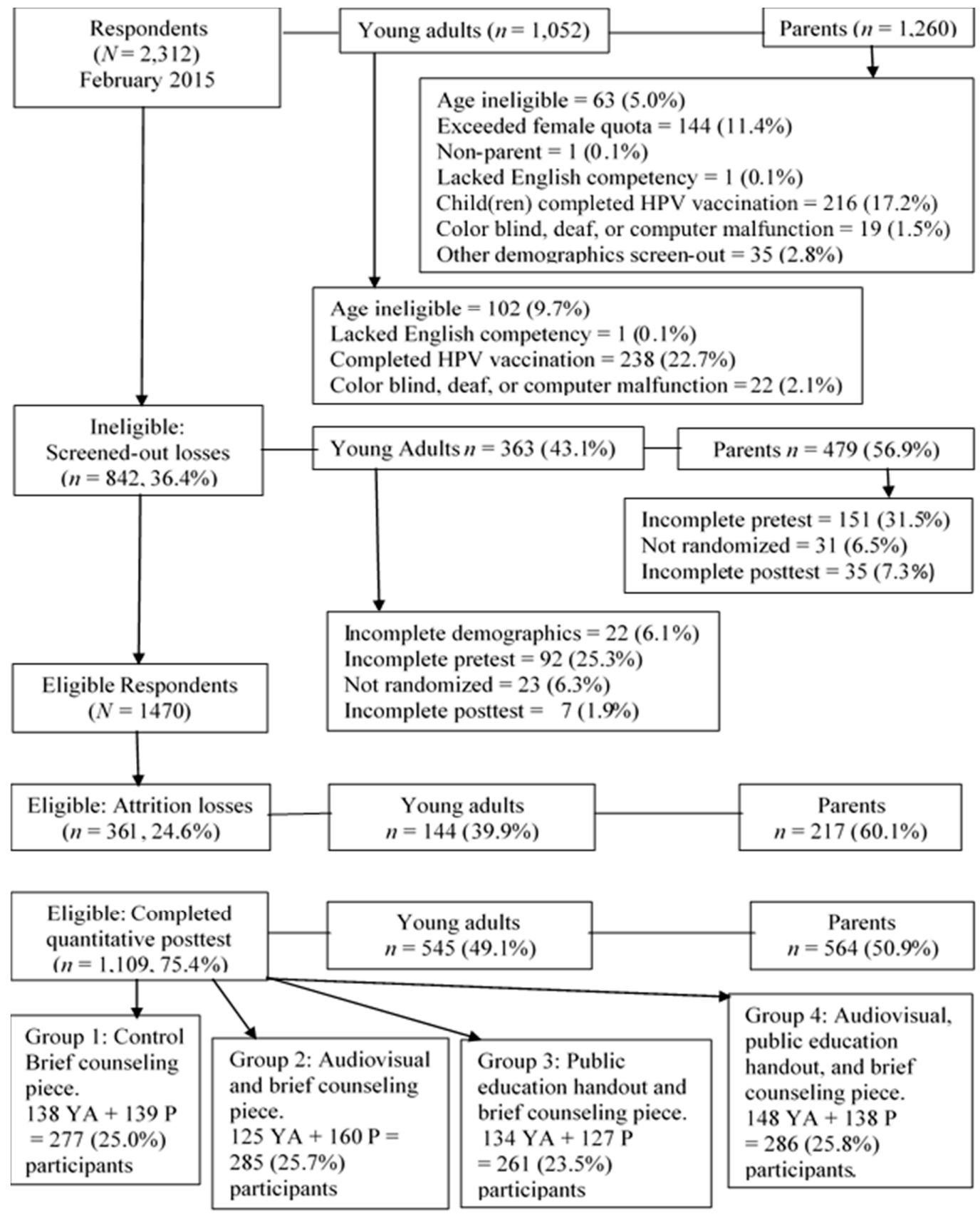

Figure 2. Participant flowchart. Sample of young adults and parents from total survey respondents. There were at least 260 participants per study group, comprised half of young adults and half of parents, with an approximately 60:40 female to male ratio, and a final sample size of 1109 participants.

Table 1. Independent variables randomization validation to group assignment.

\begin{tabular}{|c|c|c|c|c|c|c|c|c|c|c|c|c|}
\hline \multirow{2}{*}{ Independent Variables } & \multicolumn{2}{|c|}{ Control } & \multicolumn{2}{|c|}{ Exp. Gp. 1} & \multicolumn{2}{|c|}{ Exp. Gp. 2} & \multicolumn{2}{|c|}{ Exp. Gp. 3} & \multirow[t]{2}{*}{$N$} & \multirow{2}{*}{$\begin{array}{c}\text { Valid } \\
\%\end{array}$} & \multirow{2}{*}{$\begin{array}{l}\text { Chi- } \\
\text { Square }\end{array}$} & \multirow{2}{*}{$\begin{array}{c}\text { Fischer's } \\
\text { Exact Test }\end{array}$} \\
\hline & $n$ & $\%$ & $n$ & $\%$ & $n$ & $\%$ & $n$ & $\%$ & & & & \\
\hline Age (years) & & & & & & & & & & & 0.211 & \\
\hline Young adults 19-26 & 138 & 25.3 & 125 & 22.9 & 134 & 24.6 & 148 & 27.2 & 545 & 49.1 & & \\
\hline Parents 27 and older & 139 & 24.6 & 160 & 28.4 & 127 & 22.5 & 138 & 24.5 & 564 & 50.9 & & \\
\hline Biologic sex & & & & & & & & & & & 0.369 & \\
\hline Female & 151 & 23.9 & 157 & 24.8 & 160 & 25.3 & 165 & 26.1 & 633 & 57.1 & & \\
\hline Male & 126 & 26.5 & 128 & 26.9 & 101 & 21.2 & 121 & 25.4 & 476 & 42.9 & & \\
\hline
\end{tabular}


Table 1. Cont.

\begin{tabular}{|c|c|c|c|c|c|c|c|c|c|c|c|c|}
\hline \multirow{2}{*}{ Independent Variables } & \multicolumn{2}{|c|}{ Control } & \multicolumn{2}{|c|}{ Exp. Gp. 1} & \multicolumn{2}{|c|}{ Exp. Gp. 2} & \multicolumn{2}{|c|}{ Exp. Gp. 3} & \multirow[t]{2}{*}{$N$} & \multirow{2}{*}{$\begin{array}{c}\text { Valid } \\
\%\end{array}$} & Chi- & Fischer's \\
\hline & $n$ & $\%$ & $n$ & $\%$ & $n$ & $\%$ & $n$ & $\%$ & & & Square & Exact Test \\
\hline Sex of child(ren) & & & & & & & & & & & 0.225 & \\
\hline Female and male & 45 & 19.5 & 65 & 28.6 & 59 & 25.5 & 61 & 26.4 & 231 & 41.0 & & \\
\hline Male & 51 & 30.0 & 51 & 30.0 & 32 & 18.8 & 36 & 21.2 & 170 & 30.1 & & \\
\hline Female & 43 & 26.4 & 43 & 26.4 & 36 & 22.1 & 41 & 25.2 & 163 & 28.9 & & \\
\hline Marital Status & & & & & & & & & & & & $<0.001$ \\
\hline Married & 131 & 25.5 & 138 & 26.9 & 126 & 24.6 & 118 & 23.0 & 513 & 46.3 & & \\
\hline Single, never married & 110 & 27.1 & 87 & 21.4 & 100 & 24.6 & 109 & 26.8 & 406 & 36.6 & & \\
\hline Long-term relationship & 18 & 17.1 & 28 & 26.7 & 23 & 21.9 & 36 & 34.3 & 105 & 9.5 & & \\
\hline Separated, divorced, widowed & 12 & 18.5 & 26 & 40.0 & 10 & 15.4 & 17 & 26.2 & 65 & 5.8 & & \\
\hline Common law marriage & 6 & 30.0 & 6 & 30.0 & 2 & 10.0 & 6 & 30.0 & 20 & 1.8 & & \\
\hline Household size & & & & & & & & & & & 0.976 & \\
\hline One person & 25 & 28.1 & 25 & 28.1 & 15 & 16.9 & 24 & 27.0 & 89 & 8.0 & & \\
\hline Two persons & 40 & 22.9 & 46 & 26.3 & 41 & 23.4 & 48 & 27.4 & 175 & 15.8 & & \\
\hline Three persons & 82 & 24.7 & 85 & 25.6 & 76 & 22.9 & 89 & 26.8 & 332 & 29.9 & & \\
\hline Four persons & 77 & 26.1 & 71 & 24.1 & 72 & 24.4 & 75 & 25.4 & 295 & 26.6 & & \\
\hline Five persons & 30 & 23.8 & 31 & 24.6 & 33 & 26.2 & 32 & 25.4 & 126 & 11.4 & & \\
\hline Six or more persons & 23 & 25.0 & 27 & 29.3 & 24 & 26.1 & 18 & 19.6 & 92 & 8.3 & & \\
\hline Household children & & & & & & & & & & & & 0.001 \\
\hline None & 3 & 12.5 & 11 & 45.8 & 3 & 12.5 & 7 & 29.2 & 24 & 2.2 & & \\
\hline One child & 178 & 26.3 & 164 & 24.2 & 152 & 22.4 & 184 & 27.1 & 678 & 61.1 & & \\
\hline Two children & 59 & 21.1 & 83 & 29.6 & 64 & 22.9 & 74 & 26.4 & 280 & 25.2 & & \\
\hline Three children & 24 & 29.3 & 14 & 17.1 & 28 & 34.1 & 16 & 19.5 & 82 & 7.4 & & \\
\hline Four children & 9 & 36.0 & 3 & 12.0 & 10 & 40.0 & 3 & 12.0 & 25 & 2.3 & & \\
\hline Five or more children & 4 & 20.0 & 10 & 50.0 & 4 & 20.0 & 2 & 10.0 & 20 & 1.8 & & \\
\hline Race and ethnicity & & & & & & & & & & & $0.734^{a}$ & cannot \\
\hline White, non-Hispanic & 173 & 20.0 & 200 & 27.5 & 174 & 23.9 & 180 & 24.8 & 727 & 65.6 & & compute \\
\hline Hispanic, White & 34 & 27.9 & 30 & 24.6 & 30 & 24.6 & 28 & 23.0 & 122 & 11.0 & & \\
\hline African-American, non-Hispanic & 28 & 30.0 & 24 & 22.2 & 20 & 18.5 & 36 & 33.3 & 108 & 9.7 & & \\
\hline Asian, non-Hispanic & 19 & 30.0 & 19 & 25.0 & 15 & 19.7 & 23 & 30.3 & 76 & 6.9 & & \\
\hline Hispanic, non-White & 10 & 29.4 & 7 & 20.6 & 7 & 20.6 & 10 & 29.4 & 34 & 3.1 & & \\
\hline Mixed race, non-Hispanic & 7 & 28.0 & 3 & 12.0 & 9 & 36.0 & 6 & 24.0 & 25 & 2.3 & & \\
\hline Other, non-Hispanic & 5 & 38.5 & 1 & 7.7 & 5 & 38.5 & 2 & 15.4 & 13 & 1.2 & & \\
\hline Hispanic, Other & 1 & 25.0 & 1 & 25.0 & 1 & 25.0 & 1 & 25.0 & 4 & 0.4 & & \\
\hline Religion & & & & & & & & & & & & $<0.001$ \\
\hline Other Christian & 58 & 22.6 & 62 & 24.1 & 60 & 23.3 & 77 & 30.0 & 257 & 23.2 & & \\
\hline None & 68 & 28.0 & 65 & 26.7 & 52 & 21.4 & 58 & 23.9 & 243 & 21.9 & & \\
\hline Catholicism & 56 & 28.3 & 50 & 25.3 & 52 & 26.3 & 40 & 20.2 & 198 & 17.9 & & \\
\hline Baptist & 33 & 21.4 & 42 & 27.3 & 33 & 21.4 & 46 & 29.9 & 154 & 13.9 & & \\
\hline Protestantism & 24 & 24.7 & 25 & 25.8 & 27 & 27.8 & 21 & 21.6 & 97 & 8.7 & & \\
\hline Other & 21 & 22.3 & 21 & 22.3 & 23 & 24.5 & 29 & 30.9 & 94 & 8.5 & & \\
\hline Mormonism & 6 & 27.3 & 7 & 31.8 & 6 & 27.3 & 3 & 13.6 & 22 & 2.0 & & \\
\hline Jewish & 6 & 33.3 & 4 & 22.2 & 3 & 16.7 & 5 & 27.8 & 18 & 1.6 & & \\
\hline Buddhism & 3 & 21.4 & 5 & 35.7 & 2 & 14.3 & 4 & 28.6 & 14 & 1.3 & & \\
\hline Islam & 2 & 16.7 & 4 & 33.3 & 3 & 25.0 & 3 & 25.0 & 12 & 1.1 & & \\
\hline Born-again or evangelical Christian & & & & & & & & & & & 0.282 & \\
\hline Yes & 66 & 22.8 & 73 & 25.2 & 80 & 27.6 & 71 & 24.5 & 290 & 26.1 & & \\
\hline No & 211 & 25.8 & 212 & 25.9 & 181 & 22.1 & 215 & 26.3 & 819 & 73.9 & & \\
\hline Frequency of religious services & & & & & & & & & & & 0.835 & \\
\hline Rarely or never & 121 & 25.3 & 127 & 26.6 & 105 & 22.0 & 125 & 26.2 & 478 & 43.1 & & \\
\hline A few times annually & 63 & 30.1 & 49 & 23.4 & 47 & 22.5 & 50 & 23.9 & 209 & 18.8 & & \\
\hline $1-3$ times a month & 31 & 20.8 & 39 & 26.2 & 38 & 25.5 & 41 & 27.5 & 149 & 13.4 & & \\
\hline Once weekly & 44 & 22.3 & 51 & 25.9 & 49 & 24.9 & 53 & 26.9 & 197 & 17.8 & & \\
\hline More than once weekly & 18 & 23.7 & 19 & 25.0 & 22 & 28.9 & 17 & 22.4 & 76 & 6.9 & & \\
\hline Political leaning & & & & & & & & & & & 0.241 & \\
\hline Very conservative & 42 & 25.9 & 51 & 31.5 & 35 & 21.6 & 34 & 21.0 & 162 & 14.6 & & \\
\hline Somewhat conservative & 51 & 24.8 & 55 & 26.7 & 43 & 20.9 & 57 & 27.7 & 206 & 18.6 & & \\
\hline Middle of the road & 93 & 21.3 & 111 & 25.4 & 112 & 25.6 & 121 & 27.7 & 437 & 39.4 & & \\
\hline Somewhat liberal & 61 & 30.5 & 40 & 20.0 & 49 & 24.5 & 50 & 25.0 & 200 & 18.0 & & \\
\hline Very liberal & 30 & 28.8 & 28 & 26.9 & 22 & 21.2 & 24 & 23.1 & 104 & 9.4 & & \\
\hline Education level & & & & & & & & & & & 0.448 & \\
\hline Less than high school & 2 & 40.0 & 1 & 20.0 & 1 & 20.0 & 1 & 20.0 & 5 & 0.5 & & \\
\hline Some high school & 7 & 20.6 & 9 & 26.5 & 9 & 26.5 & 9 & 26.5 & 34 & 3.1 & & \\
\hline 9th grade & 2 & 15.4 & 4 & 30.8 & 3 & 23.1 & 4 & 30.8 & 13 & 1.2 & & \\
\hline 10th grade & 2 & 22.2 & 3 & 33.3 & 2 & 22.2 & 2 & 22.2 & 9 & 0.8 & & \\
\hline 11th grade & 3 & 25.0 & 2 & 16.7 & 4 & 33.3 & 3 & 25.0 & 12 & 1.1 & & \\
\hline Completed high school/GED & 59 & 25.4 & 60 & 25.9 & 61 & 26.3 & 52 & 22.4 & 232 & 20.9 & & \\
\hline Some college & 78 & 23.0 & 89 & 26.3 & 73 & 21.5 & 99 & 29.2 & 339 & 30.6 & & \\
\hline College graduate & 95 & 25.3 & 88 & 23.4 & 100 & 26.6 & 93 & 24.7 & 376 & 33.9 & & \\
\hline Graduate school & 36 & 29.3 & 38 & 30.9 & 17 & 13.8 & 32 & 26.0 & 123 & 11.1 & & \\
\hline
\end{tabular}


Table 1. Cont.

\begin{tabular}{|c|c|c|c|c|c|c|c|c|c|c|c|c|}
\hline \multirow{2}{*}{ Independent Variables } & \multicolumn{2}{|c|}{ Control } & \multicolumn{2}{|c|}{ Exp. Gp. 1} & \multicolumn{2}{|c|}{ Exp. Gp. 2} & \multicolumn{2}{|c|}{ Exp. Gp. 3} & \multirow[t]{2}{*}{$N$} & \multirow{2}{*}{$\begin{array}{c}\text { Valid } \\
\%\end{array}$} & \multirow{2}{*}{$\begin{array}{c}\text { Chi- } \\
\text { Square }\end{array}$} & \multirow{2}{*}{$\begin{array}{c}\text { Fischer's } \\
\text { Exact Test }\end{array}$} \\
\hline & $n$ & $\%$ & $n$ & $\%$ & $n$ & $\%$ & $n$ & $\%$ & & & & \\
\hline Household income & & & & & & & & & & & 0.275 & \\
\hline Less than $\$ 20,000$ & 50 & 26.2 & 46 & 24.1 & 49 & 25.7 & 46 & 24.1 & 191 & 17.2 & & \\
\hline$\$ 20,000-\$ 39,999$ & 52 & 26.1 & 43 & 21.6 & 52 & 26.1 & 52 & 26.1 & 199 & 17.9 & & \\
\hline$\$ 40,000-\$ 49,999$ & 38 & 25.2 & 41 & 27.2 & 32 & 21.2 & 40 & 26.5 & 151 & 13.6 & & \\
\hline$\$ 50,000-\$ 59,999$ & 49 & 29.0 & 36 & 21.3 & 42 & 24.9 & 42 & 24.9 & 169 & 15.2 & & \\
\hline$\$ 60,000-\$ 100,000$ & 48 & 20.3 & 76 & 32.2 & 49 & 20.8 & 63 & 26.7 & 236 & 21.3 & & \\
\hline More than $\$ 100,000$ & 28 & 28.9 & 30 & 30.9 & 16 & 16.5 & 23 & 23.7 & 97 & 8.7 & & \\
\hline Declined to answer & 12 & 18.2 & 13 & 19.7 & 21 & 31.8 & 20 & 30.3 & 66 & 6.0 & & \\
\hline Employment status & & & & & & & 0.441 & & & & 0.441 & \\
\hline Full time employee & 111 & 24.4 & 115 & 25.3 & 113 & 24.8 & & 25.5 & 455 & 41.0 & & \\
\hline Homemaker & 54 & 25.0 & 60 & 27.8 & 56 & 25.9 & & 21.3 & 216 & 19.5 & & \\
\hline Part time employee & 52 & 28.1 & 38 & 20.5 & 43 & 23.2 & & 28.1 & 185 & 16.7 & & \\
\hline Full time student, not working & 26 & 19.8 & 38 & 29.0 & 26 & 19.8 & & 31.3 & 131 & 11.8 & & \\
\hline Unemployed & 34 & 27.9 & 34 & 27.9 & 23 & 18.9 & & 25.4 & 122 & 11.0 & & \\
\hline Location of home & & & & & & & 0.923 & & & & 0.923 & \\
\hline Urban & 85 & 24.5 & 90 & 26.0 & 81 & 23.4 & & 26.0 & 346 & 31.2 & & \\
\hline Suburban & 126 & 24.3 & 134 & 25.8 & 119 & 22.9 & & 27.0 & 519 & 46.8 & & \\
\hline Rural & 66 & 27.0 & 61 & 25.0 & 61 & 25.0 & & 23.0 & 244 & 22.0 & & \\
\hline Type of health insurance & & & & & & & 0.038 * & & & & $0.038 *$ & \\
\hline Private & 146 & 22.6 & 180 & 27.8 & 143 & 22.1 & & 27.5 & 647 & 58.3 & & \\
\hline Medicaid & 80 & 29.4 & 53 & 19.5 & 74 & 27.2 & & 23.9 & 272 & 24.5 & & \\
\hline Other & 51 & 26.8 & 52 & 27.4 & 44 & 23.2 & & 22.6 & 190 & 17.1 & & \\
\hline Vaccination setting & & & & & & & 0.863 & & & & 0.863 & \\
\hline Healthcare provider's office & 195 & 25.0 & 204 & 26.2 & 183 & 23.5 & & 25.3 & 779 & 70.2 & & \\
\hline Hospital & 42 & 25.8 & 38 & 23.3 & 43 & 26.4 & & 24.5 & 163 & 14.7 & & \\
\hline Community clinic & 23 & 21.1 & 31 & 28.4 & 22 & 20.2 & & 30.3 & 109 & 9.8 & & \\
\hline County clinic & 17 & 29.3 & 12 & 20.7 & 13 & 22.4 & & 27.6 & 58 & 5.2 & & \\
\hline Frequency of healthcare visits & & & & & & & 0.579 & & & & 0.579 & \\
\hline Annual checkup & 130 & 23.0 & 15 & 27.0 & 134 & 23.8 & & 26.2 & 564 & 50.9 & & \\
\hline Only when sick & 119 & 26.1 & 115 & 25.2 & 104 & 22.8 & & 25.9 & 456 & 41.1 & & \\
\hline Other & 28 & 31.5 & 18 & 20.2 & 23 & 25.8 & & 22.5 & 89 & 8.0 & & \\
\hline Regular healthcare provider & & & & & & & 0.154 & & & & 0.154 & \\
\hline Yes & 210 & 23.6 & 232 & 26.1 & 209 & 23.5 & & 26.8 & 889 & 80.2 & & \\
\hline No & 67 & 30.5 & 53 & 24.1 & 52 & 23.6 & & 21.8 & 220 & 19.8 & & \\
\hline US Generation $^{b}(n=1108)$ & & & & & & & 0.321 & & & & 0.321 & \\
\hline First generation & 38 & 30.9 & 30 & 24.4 & 23 & 18.7 & & 26.0 & 123 & 12.1 & & \\
\hline Second generation & 38 & 28.1 & 26 & 19.3 & 31 & 23.0 & & 29.6 & 135 & 13.3 & & \\
\hline Third generation & 180 & 23.7 & 204 & 26.8 & 178 & 23.4 & & 26.1 & 760 & 74.7 & & \\
\hline Know someone with a STD & & & & & & & 0.625 & & & & 0.625 & \\
\hline Yes & 101 & 24.8 & 97 & 23.8 & 103 & 25.3 & & 26.0 & 407 & 36.7 & & \\
\hline No & 176 & 25.1 & 188 & 26.8 & 158 & 22.5 & & 25.6 & 702 & 63.3 & & \\
\hline Personally had a STD & & & & & & & 0.555 & & & & 0.555 & \\
\hline Yes & 27 & 23.3 & 25 & 21.6 & 32 & 27.6 & & 27.6 & 116 & 10.5 & & \\
\hline No & 250 & 25.2 & 260 & 26.2 & 229 & 23.1 & & 25.6 & 993 & 89.5 & & \\
\hline Ever heard of HPV & & & & & & & 0.850 & & & & 0.850 & \\
\hline Yes & 221 & 25.0 & 230 & 26.0 & 210 & 23.8 & & 25.2 & 884 & 79.7 & & \\
\hline No & 56 & 24.9 & 55 & 24.4 & 51 & 22.7 & & 28 & 225 & 20.3 & & \\
\hline Ever heard of HPV vaccine & & & & & & & 0.684 & & & & 0.684 & \\
\hline Yes & 214 & 25.3 & 215 & 25.4 & 204 & 24.1 & & 25.1 & 845 & 76.2 & & \\
\hline No & 63 & 23.9 & 70 & 26.5 & 57 & 21.6 & & 28.0 & 264 & 23.8 & & \\
\hline $\begin{array}{l}\text { Offered HPV vaccine for child(ren) } \\
\text { or self }\end{array}$ & & & & & & & 0.566 & & & & 0.566 & \\
\hline Yes & 82 & 22.7 & 92 & 25.5 & 92 & 25.5 & & 26.3 & 361 & 32.6 & & \\
\hline No & 195 & 26.1 & 193 & 25.8 & 169 & 22.6 & & 25.5 & 748 & 67.4 & & \\
\hline Accepted HPV vaccine ${ }^{c}(n=218)$ & & & & & & & & & & & $0.029 *$ & \\
\hline Yes & 61 & 27.1 & 54 & 24.0 & 47 & 20.9 & 63 & 28.0 & 218 & 60.4 & & \\
\hline No & 26 & 17.3 & 38 & 25.3 & 49 & 32.7 & 37 & 24.7 & 143 & 39.6 & & \\
\hline HPV vaccine doses $^{d}(n=219)$ & & & & & & & & & 219 & & 0.054 & \\
\hline None & 3 & 25.0 & 1 & 8.3 & 6 & 50.0 & 2 & 16.7 & 12 & 5.5 & & \\
\hline One dose & 39 & 26.9 & 40 & 27.6 & 22 & 15.2 & 44 & 30.3 & 145 & 66.21 & & \\
\hline Two doses & 16 & 25.8 & 54 & 21.0 & 18 & 29.0 & 15 & 24.2 & 62 & 28.3 & & \\
\hline
\end{tabular}

${ }^{a} 8$ cells $(25 \%)$ have expected count less than 5 , Yates continuity correction. $734=$ Pearson Chi-Square. ${ }^{b}(n=1108)$ as there were 91 foreign born participants. ${ }^{c}(n=218)$ is the number of included participants who were offered and accepted HPV vaccine, but who did not complete the 3-dose HPV vaccination series. ${ }^{d}(n=219)$ includes one subject who was not offered, but received HPV vaccine. * denotes statistical significance the alpha $=p=0.05$ level. Due to rounding percentages may not add up to 100. Exp. Gp. = Experimental Group; GED = General education development certificate; $\mathrm{HPV}=$ Human papilloma virus; $\mathrm{STD}=$ sexually transmitted disease; $\mathrm{US}=$ = United States of America. 
The online survey host, SurveyMonkey Audience, directly invited potential participants from its database and maintained the anonymity of potential and actual study participants. Data lacking identifiers, IP, or email address tracking was collected via encrypted secure sockets layer/transport layer security technology (SSL/TLS) connections in February 2015. The survey lacked name, address, or contact information fields. Participant data storage followed the standard SurveyMonkey Audience anonymous data storage protocol: user authentication and user passwords for data access, and continued data encryption while stored in an audited secure data center.

Statistical analysis was performed using IBM SPSS Statistics (IBM Corp., Armonk, NY, USA), package Version 22. Normality testing with Kolmogorov-Smirnov and Shapiro-Wilk tests at $p<0.05$ ascertained a lack of normally distributed demographics, knowledge, and acceptance items responses. Therefore, count and frequency descriptive statistics were used for the sample description. Chi-square was used to ascertain randomization validity. Spearman's rank correlation coefficient $(\varrho)$ was used for comparisons between interval and ordinal variables [31].

Quantitative HPV knowledge and HPV vaccination acceptance items were analyzed for the 1109 respondents who completed the survey through the end of the quantitative post-test. Responses were extracted and analyzed as two groups, as well as individually. Given the lack of normality and the use of four study groups, two-tailed non-parametric tests at alpha level $\alpha \leq 0.05$ were employed: Kruskal-Wallis analysis of variance by ranks $\left(\chi^{2}\right)$, Mann-Whitney $U$ test with Bonferroni correction, and Wilcoxon signed-ranks test $(T)$.

\section{Results}

Childless young adults who had not completed a HPV vaccination series and parents whose child(ren) had not completed a HPV vaccination series were the study population. Prior completion of the HPV vaccination series was the primary cause of study ineligibility (Figure 2). The study had a $75.4 \%$ completion rate. Pre-test attrition was the most common form of attrition loss (67.3\%). Table 1 and Figures S1-S4 describe the 1109 respondents who completed the survey through the end of the quantitative post-test. The resulting sample had a positively skewed age distribution, comprised of 545 childless young adults ages 19-26, and 564 parents age 27 years or older (Figure 2, Figures S1-S4 and Table 1). Childless young adults were more likely to have never married than were parents $(64.8 \%$ and $9.4 \%$ respectively), and more likely to have had some college education than parents (35\% and $26.2 \%$ respectively). However, parents were more likely to have graduated from college or graduate school than were childless young adults $(41.1 \%$ and $16.5 \%$ versus $26.4 \%$ and $5.5 \%$, respectively). Parents were more likely to accept offers of HPV vaccination for a child than were childless young adults for themselves (68.2\% versus $52.9 \%$, respectively).

Chi-square analysis ascertained valid random assignment of participants to intervention groups based on 15 nominal independent variables excluding insurance status, marital status, race and ethnicity, and religion (Table 1). Human Papilloma Virus vaccination acceptance and insurance type were imbalanced ( $p=0.029$ and $p=0.038$ respectively) (Table 1 ). Due to category assignments of less than five per intervention group, 2-sided Fisher's exact tests were calculated for marital status and religion, resulting in $p<0.001$ in each case. For race and ethnicity, one-quarter of Pearson Chi-Square cells had expected cell frequencies of fewer than 5 participants. Fisher's exact test could not be run. The Yates Continuity Correction and the Pearson Chi-Square were equal at 0.734.

To determine differences in pre- to post-test knowledge of HPV-attributable diseases and prophylaxis between multimodal counseling interventions for HPV vaccination among series non-completers, the change in number of participants making agree or strongly agree responses to the 11-item knowledge variable subscale was analyzed (Tables $2-4)$. Kruskal-Wallis analysis of variance by ranks $\left(\chi^{2}\right)$ of the $18.0 \%$ to $19.9 \%$ increases in the number of participants with knowledge subscale agree or strongly agree responses in Groups 2 and 3 indicated statistical significance, $p=0.038$ (Table 3). Follow-up Mann-Whitney $U$ testing with Bonferroni correction, showed Group 2 had statistically significant increases in the number of participants with more than half knowledge subscale agree or strongly agree responses $(p=0.04)$ as 
shown in Table 5. Groups 2 and 3 achieved statistically significant knowledge improvement of HPV etiologic role in occurrence of EGW, $p<0.001$. Group 3 achieved statistically significant knowledge improvement pertaining to the purposes of HPV vaccination, $p=0.02$. Wilcoxon signed-ranks test identified six knowledge items with statistically significant changes in responses using the range of the 5-point Likert scale from pre-test to post-test, with small or medium effect sizes as shown in Table 6 [32].

To determine the effect, if any, of covariates on HPV knowledge and HPV vaccination acceptance, Spearman's rank correlation coefficient $(\varrho)$ was calculated. Unadjusted $\varrho$, demonstrated that parents' age in years, and US generation status were significantly correlated with increased HPV knowledge ( $p=0.027$ and $p=0.032$ respectively) and HPV vaccination acceptance $(p=0.005$ and $p=0.032$ respectively), resulting in more than half agree and strongly agree responses (Table 7). The number of doses of HPV vaccine received affected increased HPV vaccination acceptance $(p=0.011)$, while the number of male children a parent had was significantly correlated ( $p=0.028)$ with increased HPV knowledge resulting in more than half agree and strongly agree responses.

To ascertain differences in reported HPV vaccination acceptance rates of HPV vaccination series non-completers across multimodal counseling interventions, the pre-test to post-test change in the number of participants responding agree or strongly agree to the 14-item acceptance variable subscale items was analyzed. Kruskal-Wallis analysis of variance by ranks $\left(\chi^{2}\right)$ of the $12.2 \%$ to $12.6 \%$ increases in the number of participants with acceptance subscale agree or strongly agree responses in Groups 1 and 3 respectively (Table 3) did not demonstrate statistical significance. Wilcoxon signed-ranks test indicated eight HPV vaccination acceptance items with statistically significant changes in responses using the 5-point Likert scale from pre-test to post-test, $p<0.001$ to $p=0.023$; however, the effect sizes were small or medium as shown in Table 6 [32]. For Group 1, the audiovisual intervention, there were six such items: "A3. Research improves vaccines", $p=0.006$, "A5. HPV vaccination would prevent problems for myself/my child(ren)", $p=0.002$, "A7. HPV vaccination before teenage is a good idea", $p=0.002$, "A9. If the HPV vaccine were available, I/my child(ren) would be vaccinated against HPV”, $p=0.002$, “A12. Despite cost I will vaccinate myself/my child(ren)", $p<0.001$, and "A13. If my doctor recommends I will vaccinate myself/my child(ren)", $p=0.042$. For Group 3, the combined audiovisual and PHEH intervention, there were seven such items: "A3. Research improves vaccines", $p=0.001$, "A5. HPV vaccination would prevent problems for myself/my child(ren)", $p<0.001$, "A7. HPV vaccination before teenage is a good idea", $p=0.001$, "A8. Teenagers should be able to get HPV vaccination without parental consent", $p=0.023$, "A11. Will only vaccinate myself/my child(ren) against HPV if required", $p=0.002$, "A12. Despite cost I will vaccinate myself/my child(ren)", $p<0.001$, and "A13. If my doctor recommends I will vaccinate myself/my child(ren)" ${ }^{\prime \prime} p=0.05$. 
Table 2. Intervention group scale summary: More than half post-test responses showing HPV Knowledge and HPV vaccination acceptance.

\begin{tabular}{|c|c|c|c|c|c|c|c|c|c|c|c|c|c|c|c|c|c|c|c|c|}
\hline \multirow{2}{*}{ Scale } & \multicolumn{4}{|c|}{ Control $^{a}(n=277)$} & \multicolumn{4}{|c|}{ Exp. Group $1^{b}(n=285)$} & \multicolumn{4}{|c|}{ Exp. Group $2^{c}(n=261)$} & \multicolumn{4}{|c|}{ Exp. Group $3^{d}(n=286)$} & \multicolumn{4}{|c|}{ All Groups ${ }^{e}(n=1109)$} \\
\hline & Pre & Post & Diff. & $\%$ & Pre & Post & Diff. & $\%$ & Pre & Post & Diff. & $\%$ & Pre & Post & Diff. & $\%$ & Pre & Post & Diff. & $\%$ \\
\hline Knowledge subscale & 147 & 171 & 24 & 8.7 & 154 & 194 & 40 & 14.0 & 136 & 183 & 47 & 18.0 & 144 & 201 & 57 & 19.9 & 581 & 749 & 168 & 15.1 \\
\hline Acceptance subscale & 87 & 113 & 26 & 9.4 & 105 & 141 & 36 & 12.6 & 95 & 116 & 21 & 8.0 & 103 & 138 & 35 & 12.2 & 390 & 508 & 118 & 10.6 \\
\hline
\end{tabular}

${ }^{a}(n=277)$ is the number of participants in the Control group. ${ }^{b}(n=285)$ is the number of participants in Experimental Group 1. ${ }^{c}(n=261)$ is the number of participants in Experimental Group 2. ${ }^{d}(n=286)$ is the number of participants in Experimental Group 3. ${ }^{e}(n=1109)$ is the number of participants who completed the survey through the quantitative post-test; the sum of the participants in each of the intervention groups. Diff = pre- to post-test change; Exp. $=$ Experimental; Pre $=$ Pre-test; Post = Post-test.

Table 3. Intervention group scale analysis: More than half post-test responses showing HPV Knowledge and HPV vaccination acceptance.

\begin{tabular}{|c|c|c|c|c|c|c|c|}
\hline \multirow[t]{2}{*}{ Scale } & \multirow{2}{*}{$\begin{array}{c}\text { Control }^{a}(n=277) \\
\begin{array}{c}\text { Kruskal-Wallis } \\
\text { Mean Rank }\end{array}\end{array}$} & \multirow{2}{*}{$\begin{array}{c}\text { Exp. Group } 1^{b}(n=285) \\
\begin{array}{c}\text { Kruskal-Wallis } \\
\text { Mean Rank }\end{array}\end{array}$} & \multirow{2}{*}{$\begin{array}{c}\text { Exp. Group } 2{ }^{c}(n=261) \\
\begin{array}{c}\text { Kruskal-Wallis } \\
\text { Mean Rank }\end{array}\end{array}$} & \multirow{2}{*}{$\begin{array}{c}\text { Exp. Group } 3^{d}(n=286) \\
\text { Kruskal-Wallis } \\
\text { Mean Rank }\end{array}$} & \multicolumn{3}{|c|}{$\begin{array}{c}\text { Across/between Groups } \\
\text { Comparison }\end{array}$} \\
\hline & & & & & Chi-Square & $d f$ & $p$ Value \\
\hline \multicolumn{8}{|l|}{ Knowledge Subscale } \\
\hline $\begin{array}{l}\text { Change > half overall Responses Agree } \\
\text { or Strongly Agree }\end{array}$ & 517.89 & 540.04 & 585.31 & 578.18 & 8.443 & 3 & $0.038^{*}$ \\
\hline 3. HPV causes genital warts & 514.47 & 506.13 & 604.96 & 597.37 & 34.887 & 3 & $<0.001$ ** \\
\hline 9. I know what the HPV vaccine is for & 522.18 & 548.34 & 561.97 & 587.06 & 8.556 & 3 & $0.036^{*}$ \\
\hline $\begin{array}{l}\text { Acceptance Subscale } \\
\text { Change > half Overall Responses Agree } \\
\text { or Strongly Agree }\end{array}$ & 531.84 & 571.39 & 550.14 & 565.53 & 2.628 & 3 & 0.453 \\
\hline
\end{tabular}

$a(n=277)$ is the number of participants in the Control group. ${ }^{b}(n=285)$ is the number of participants in Experimental Group $1 .{ }^{c}(n=261)$ is the number of participants in Experimental Group 2. ${ }^{d}(n=286)$ is the number of participants in Experimental Group 3. ${ }^{*}$ denotes significant 2-tailed correlation at the alpha $=p=0.05$ level. $d f=$ degrees of freedom; ${ }^{* *}$ denotes significant 2-tailed correlation at the alpha $=p=0.01$ level; ; Exp. = Experimental. 
Table 4. Intervention group knowledge item summary: Per group respondents with more than half post-test responses showing HPV Knowledge.

\begin{tabular}{|c|c|c|c|c|c|c|c|c|c|c|c|c|c|c|c|c|c|c|c|c|}
\hline \multirow{3}{*}{ Knowledge Subscale Items } & \multicolumn{4}{|c|}{ Control $^{a}(n=277)$} & \multicolumn{4}{|c|}{ Exp. Group $1^{b}(n=285)$} & \multicolumn{4}{|c|}{ Exp. Group $2^{c}(n=261)$} & \multicolumn{4}{|c|}{ Exp. Group $3^{d}(n=286)$} & \multicolumn{4}{|c|}{ Overall $^{e}(n=1109)$} \\
\hline & \multicolumn{2}{|c|}{ Pre-test } & \multicolumn{2}{|c|}{ Post-test } & \multicolumn{2}{|c|}{ Pre-test } & \multicolumn{2}{|c|}{ Post-test } & \multicolumn{2}{|c|}{ Pre-test } & \multicolumn{2}{|c|}{ Post-test } & \multicolumn{2}{|c|}{ Pre-test } & \multicolumn{2}{|c|}{ Post-test } & \multicolumn{2}{|c|}{ Pre-test } & \multicolumn{2}{|c|}{ Post-test } \\
\hline & No. & $\%$ & No. & $\%$ & No. & $\%$ & No. & $\%$ & No. & $\%$ & No. & $\%$ & No. & $\%$ & No. & $\%$ & No. & $\%$ & No. & $\%$ \\
\hline & 119 & 42.96 & 127 & 45.85 & 137 & 48.07 & 140 & 49.13 & 117 & 44.83 & 173 & 66.28 & 124 & 43.36 & 180 & 62.94 & 497 & 44.82 & 620 & 55.91 \\
\hline 9. I know what the HPV vaccine is for & 103 & 37.18 & 149 & 53.79 & 135 & 47.37 & 197 & 69.12 & 106 & 40.61 & 170 & 65.13 & 117 & 40.91 & 201 & 70.28 & 461 & 41.57 & 717 & 64.65 \\
\hline
\end{tabular}

${ }^{a}(n=277)$ is the number of participants in the Control group. ${ }^{b}(n=285)$ is the number of participants in Experimental Group 1. ${ }^{c}(n=261)$ is the number of participants in Experimental Group 2. ${ }^{d}(n=286)$ is the number of participants in Experimental Group 3. ${ }^{e}(n=1109)$ is the number of participants who completed the survey through the quantitative post-test; the sum of the participants in each of the intervention groups. Exp. = Experimental; * denotes significant 2-tailed correlation at the alpha $=p=0.05$ level. ${ }^{* *}$ denotes significant 2 -tailed correlation at the alpha $=p=0.01$ level.

Table 5. Intervention group summary: Changes in responses on the HPV knowledge and HPV vaccination acceptance subscales.

\begin{tabular}{|c|c|c|c|c|c|c|c|}
\hline Subscale Item & $\begin{array}{l}\text { Paired Groups for Comparison Group: } \\
\text { Intervention }\end{array}$ & $n$ & Mean Rank & Mann-Whitney $U$ & $z$ & $p$ Value & $\begin{array}{c}\text { Bonferroni } \\
\text { Corrected } p \text { Value }\end{array}$ \\
\hline \multirow[t]{3}{*}{ Change in Agree and Strongly Agree } & Control group: Control & 277 & 276.37 & & & & \\
\hline & Exp. Group 1: Control and Audiovisual & 285 & 286.48 & $38,052.00$ & -0.750 & 0.453 & \\
\hline & Control group: Control & 277 & 253.06 & & & & \\
\hline \multirow[t]{3}{*}{ Knowledge Responses over $50 \%$ mark } & Exp. Group 2: Control and Handout & 261 & 286.94 & $31,595.50$ & -2.573 & 0.010 & 0.04 * \\
\hline & Control group: Control & 277 & 266.46 & & & & \\
\hline & Exp. Group 3: Control, Audiovisual and Handout & 286 & 297.05 & $35,305.50$ & -2.272 & 0.023 & 0.092 \\
\hline \multirow{6}{*}{ K3. HPV causes genital warts } & Control group: Control & 277 & 283.78 & & & & \\
\hline & Exp. Group 1: Control and Audiovisual & 285 & 279.28 & $38,840.50$ & -0.437 & 0.662 & \\
\hline & Control group: Control & 277 & 247.98 & & & & \\
\hline & Exp. Group 2: Control and Handout & 261 & 292.34 & $30,188.50$ & -4.193 & $<0.001$ & $<0.001 * *$ \\
\hline & Control group: Control & 277 & 260.70 & & & & \\
\hline & Exp. Group 3: Control, Audiovisual and Handout & 286 & 302.63 & $33,711.00$ & -3.778 & $<0.001$ & $<0.001$ ** \\
\hline \multirow{6}{*}{ K9. I know what the HPV vaccine is for } & Control group: Control & 277 & 274.73 & & & & \\
\hline & Exp. Group 1: Control and Audiovisual & 285 & 288.08 & $37,597.50$ & -1.181 & 0.238 & \\
\hline & Control group: Control & 277 & 260.10 & & & & \\
\hline & Exp. Group 2: Control and Handout & 261 & 279.47 & $33,546.00$ & -1.741 & 0.082 & \\
\hline & Control group: Control & 277 & 265.35 & & & & \\
\hline & Exp. Group 3: Control, Audiovisual and Handout & 286 & 298.13 & $34,998.50$ & -2.832 & 0.005 & $0.02 *$ \\
\hline \multirow[t]{3}{*}{ Change in Agree and Strongly Agree } & Control group: Control & 277 & 271.62 & & & & \\
\hline & Exp. Group 1: Control and Audiovisual & 285 & 291.11 & $36,734.50$ & -1.439 & 0.150 & \\
\hline & Control group: Control & 277 & 264.85 & & & & \\
\hline \multirow[t]{3}{*}{ Acceptance Responses over 50\% mark } & Exp. Group 2: Control and Handout & 261 & 274.43 & $34,861.00$ & -0.725 & 0.468 & \\
\hline & Control group: Control & 277 & 273.38 & & & & \\
\hline & Exp. Group 3: Control, Audiovisual and Handout & 286 & 290.35 & $37,222.00$ & -1.253 & 0.210 & \\
\hline
\end{tabular}

Exp. = Experimental; $\mathrm{K}=$ Knowledge subscale item; * denotes significant 2-tailed correlation at the alpha $=p=0.05$ level using the mathematically equivalent Bonferroni adjustment of calculated $p$ value $\times 4 .{ }^{* *}$ denotes significant 2 -tailed correlation at the alpha $=p=0.01$ level using the mathematically equivalent Bonferroni adjustment of calculated $p$ value $\times 4$. 
Table 6. Per question summary: Wilcoxon signed ranks test analysis of pre-test to post-test response changes.

\begin{tabular}{|c|c|c|c|c|c|c|c|c|c|c|}
\hline \multirow{2}{*}{ Question } & \multicolumn{5}{|c|}{ Control Group $^{a}(n=277),{ }^{A}(N=554)$} & \multicolumn{5}{|c|}{ Experimental Group $1^{b}(n=285),{ }^{B}(N=570)$} \\
\hline & $\begin{array}{l}\text { Median } \\
\text { Pre-test }\end{array}$ & $\begin{array}{l}\text { Median } \\
\text { Post-test }\end{array}$ & $z$ & $p$ & Effect Size $r$ & $\begin{array}{l}\text { Median } \\
\text { Pre-test }\end{array}$ & $\begin{array}{l}\text { Median } \\
\text { Post-test }\end{array}$ & $z$ & $p$ & Effect Size $r$ \\
\hline $\mathrm{K} 1 . \mathrm{HPV}$ is a STD & Agree (4) & Agree (4) & -3.944 & $<0.001 * *$ & $0.168^{\mathrm{s}}$ & Agree (4) & Agree (4) & -3.239 & $0.001 * *$ & $0.136^{\mathrm{s}}$ \\
\hline K2. Condoms prevent HPV & Agree (4) & Agree (4) & -1.563 & 0.118 & 0.066 & Agree (4) & Neutral (3) & -0.134 & 0.893 & 0.006 \\
\hline K4. People with HPV may be asymptomatic & Agree (4) & Agree (4) & -1.823 & 0.068 & 0.077 & Agree (4) & Agree (4) & -0.876 & 0.381 & 0.037 \\
\hline K5. HPV causes sterility & Neutral (3) & Neutral (3) & -3.030 & $0.002 * *$ & $0.129^{\mathrm{s}}$ & Neutral (3) & Neutral (3) & -1.471 & 0.141 & 0.062 \\
\hline A1. Worry that I/my child(ren)can get HPV & Neutral (3) & Neutral (3) & -3.879 & $<0.001$ ** & $0.165^{\mathrm{s}}$ & Neutral (3) & Neutral (3) & -4.078 & $<0.001 * *$ & $0.171^{\mathrm{s}}$ \\
\hline K6. HPV causes cervical cancer & Agree (4) & Agree (4) & -3.724 & $<0.001$ ** & $0.158^{\mathrm{s}}$ & Agree (4) & Agree (4) & -4.336 & $<0.001 * *$ & $0.182^{\mathrm{s}}$ \\
\hline K7. Treatment of HPV is painful & Neutral (3) & Neutral (3) & -1.576 & 0.115 & 0.067 & Neutral (3) & Neutral (3) & -0.858 & 0.391 & 0.036 \\
\hline $\begin{array}{l}\text { K9. I know what the HPV vaccine is for } \\
\text { K10. Genital warts make it hard to have a sexual partner }\end{array}$ & $\begin{array}{l}\text { Neutral (3) } \\
\text { Agree (4) }\end{array}$ & $\begin{array}{l}\text { Agree (4) } \\
\text { Agree (4) }\end{array}$ & $\begin{array}{l}-6.689 \\
-0.845\end{array}$ & $<0.001 *$ & $0.284^{\mathrm{m}}$ & Neutral (3) & $\begin{array}{l}\text { Agree (4) } \\
\text { Agree (4) }\end{array}$ & -6.924 & $<0.001 * *$ & $0.029^{\mathrm{s}}$ \\
\hline $\begin{array}{l}\text { K10. Genital warts make it hard to have a sexu } \\
\text { K11. Children should only be vaccinated for }\end{array}$ & Agree (4) & Agree (4) & -0.845 & 0.398 & 0.036 & Agree (4) & Agree (4) & -1.289 & 0.197 & 0.054 \\
\hline serious diseases & Neutral (3) & Neutral (3) & -0.524 & 0.600 & 0.022 & Neutral (3) & Neutral (3) & -0.320 & 0.749 & 0.013 \\
\hline $\begin{array}{l}\text { A2. Vaccines that have been used awhile are more } \\
\text { trustworthy }\end{array}$ & Agree (2) & Agree (2) & -1.547 & 0.122 & 0.066 & Agree (2) & Agree (2) & -1.068 & 0.285 & 0.045 \\
\hline $\begin{array}{l}\text { A3. Research improves vaccines } \\
\text { A4. Healthy children do not need vaccines }\end{array}$ & $\begin{array}{c}\text { Agree (4) } \\
\text { Disagree (4) }\end{array}$ & $\begin{array}{c}\text { Agree (4) } \\
\text { Disagree (4) }\end{array}$ & $\begin{array}{l}-1.122 \\
-1.506\end{array}$ & $\begin{array}{l}0.262 \\
0.132\end{array}$ & $\begin{array}{l}0.048 \\
0.064\end{array}$ & $\begin{array}{c}\text { Agree (4) } \\
\text { Disagree (4) }\end{array}$ & $\begin{array}{c}\text { Agree (4) } \\
\text { Disagree (4) }\end{array}$ & $\begin{array}{l}-2.763 \\
-1.898\end{array}$ & $\begin{array}{c}0.006^{* *} \\
0.058\end{array}$ & $\begin{array}{c}0.116^{\mathrm{s}} \\
0.079\end{array}$ \\
\hline $\begin{array}{l}\text { A5. HPV vaccination would prevent problems for } \\
\text { myself/my child(ren) }\end{array}$ & Neutral (3) & Agree (4) & -3.088 & $0.002 * *$ & $0.131^{\mathrm{s}}$ & Agree (4) & Agree (4) & -3.130 & $0.002 * *$ & $0.131^{\mathrm{s}}$ \\
\hline $\begin{array}{l}\text { A8. Teenagers should be able to get HPV vaccination } \\
\text { without parental consent }\end{array}$ & Neutral (3) & Neutral (3) & -1.243 & 0.214 & 0.053 & Neutral (3) & Neutral (3) & -0.958 & 0.338 & 0.040 \\
\hline $\begin{array}{l}\text { A9. If the HPV vaccine were available, I/my child(ren) } \\
\text { would be vaccinated against HPV }\end{array}$ & Neutral (3) & Neutral (3) & -1.250 & 0.211 & 0.053 & Neutral (3) & Neutral (3) & -2.748 & $0.006 * *$ & $0.115^{\mathrm{s}}$ \\
\hline $\begin{array}{l}\text { A10. Vaccines are painful, so I would not vaccinate } \\
\text { myself/my child(ren) }\end{array}$ & Neutral (3) & Disagree (4) & -0.707 & 0.480 & 0.030 & Disagree (4) & Disagree (4) & -1.110 & 0.267 & 0.046 \\
\hline $\begin{array}{l}\text { A11. Will only vaccinate myself/my child(ren) against } \\
\text { HPV if required }\end{array}$ & Neutral (3) & Neutral (3) & -1.968 & $0.049 *$ & $0.084^{\mathrm{s}}$ & Neutral (3) & Neutral (3) & -1.174 & 0.240 & 0.049 \\
\hline A12. Despite cost I will vaccinate myself/my child(ren) & Neutral (3) & Neutral (3) & -2.332 & $0.020^{*}$ & $0.099^{\mathrm{s}}$ & Neutral (3) & Neutral (3) & -3.623 & $<0.001^{* *}$ & $0.152^{\mathrm{s}}$ \\
\hline $\begin{array}{l}\text { A13. If my doctor recommends I will vaccinate myself/my } \\
\text { child(ren) }\end{array}$ & Agree (4) & Agree (4) & -0.555 & 0.579 & 0.024 & Agree (4) & Agree (4) & -2.035 & $0.042 *$ & $0.085^{\mathrm{s}}$ \\
\hline $\begin{array}{l}\text { A14. When I decide to vaccinate myself/my child(ren) it } \\
\text { will be done }\end{array}$ & Agree (4) & Agree (4) & -0.091 & 0.927 & 0.004 & Agree (4) & Agree (4) & -1.236 & 0.217 & 0.052 \\
\hline
\end{tabular}


Table 6. Cont.

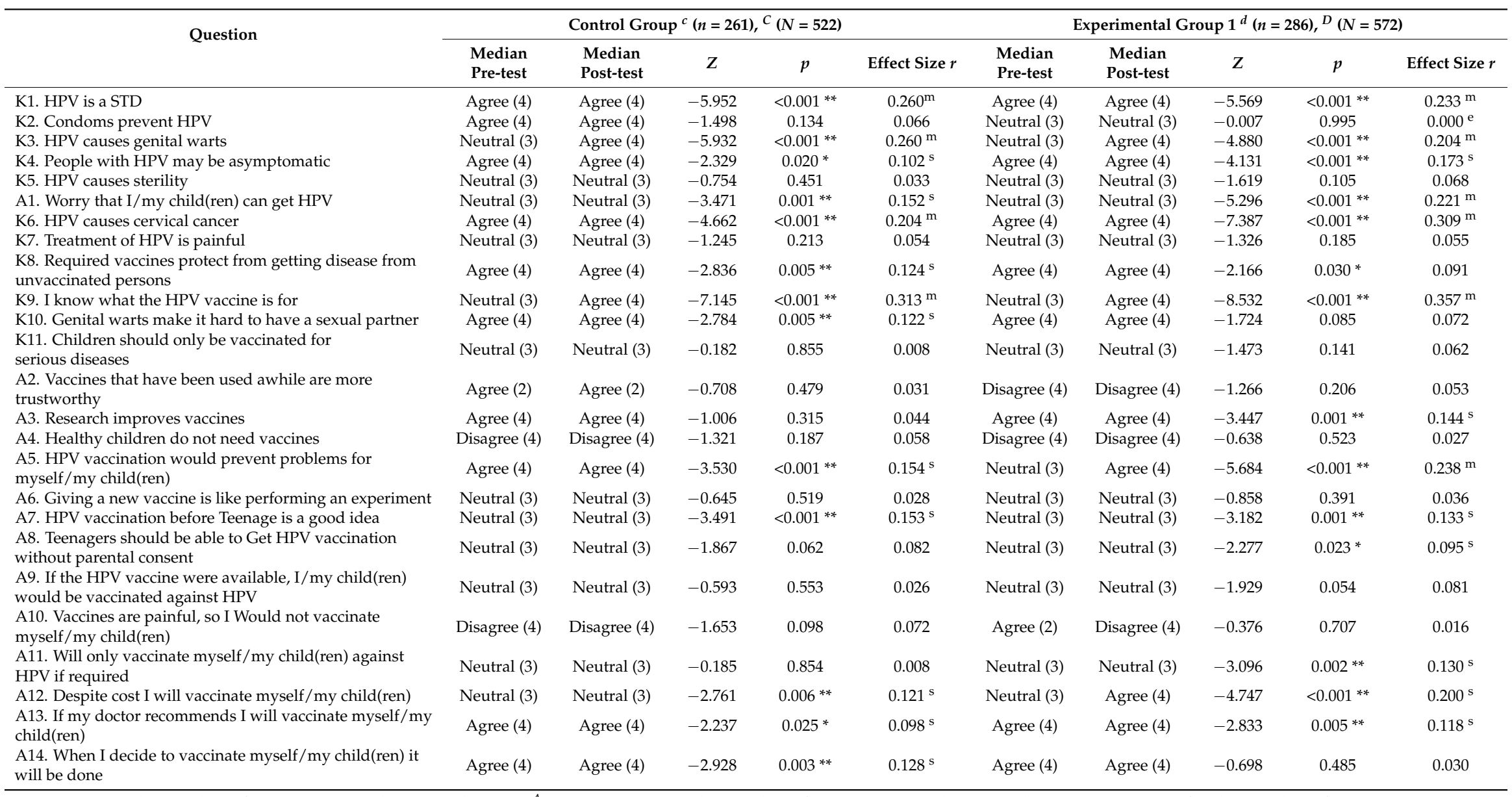

${ }^{a}(n=277)$ is the number of participants in the Control group. ${ }^{A}(N=554)$ is twice the number of participants in the Control group, accounting for the number of pre- and post-tests. ${ }^{b}(n=285)$ is the number of participants in Experimental Group 1. ${ }^{B}(N=554)$ is twice the number of participants in Experimental Group 1, accounting for the number of pre- and post-tests. ${ }^{c}(n=261)$ is the number of participants in Experimental Group 2. ${ }^{C}(N=554)$ is twice the number of participants in Experimental Group 2, accounting for the number of pre- and post-tests. $d(n=286)$ is the number of participants in Experimental Group 3. ${ }^{D}(N=554)$ is twice the number of participants in Experimental Group 3, accounting for the number of pre- and post-tests. $\mathrm{A}=$ Acceptance subscale item; $\mathrm{K}=$ Knowledge subscale item; $\mathrm{e}=$ actual $\mathrm{r}$ value is $.0003 ; \mathrm{m}=$ medium effect size; $\mathrm{s}=$ small effect size. ${ }^{*}$ denotes significant 2 -tailed correlation at the alpha $=$ $p=0.05$ level. ${ }^{* *}$ denotes significant 2-tailed correlation at the alpha $=p=0.01$ level. 
Table 7. Covariates affect HPV knowledge and HPV vaccination acceptance pre-test to post-test change.

\begin{tabular}{lcccc}
\hline \multirow{2}{*}{ Covariate } & \multicolumn{2}{c}{ Knowledge Subscale Change } & \multicolumn{2}{c}{ Acceptance Subscale Change } \\
\cline { 2 - 5 } & Spearman's $\varrho$ & Significance, 2-Tailed & Spearman's $\varrho$ & Significance, 2-Tailed \\
\hline Young Adults' Actual Age in Years & -0.011 & 0.796 & 0.073 & 0.088 \\
Parents' Actual Age in Years & 0.093 & $0.027^{*}$ & 0.119 & 0.008 \\
Number of Female Children & 0.017 & 0.690 & 0.017 & 0.846 \\
Number of Male Children & 0.093 & $0.028^{*}$ & -0.171 & 0.693 \\
Number of HPV Vaccine Doses & 0.092 & 0.176 & 0.041 & $0.011^{*}$ \\
Child(ren) or Young Adult Received & 0.008 & 0.799 & 0.067 & 0.171 \\
Household Size & 0.016 & 0.602 & 0.102 & 0.084 \\
Number of Children in the Household & 0.067 & $0.032 *$ & 0.026 \\
Generations Born in the US & -0.085 & 0.425 & 0.023 \\
Non-US Born: Years Lived in the US & 0.025 & 0.403 & 0.156 \\
Religious Services Frequency & -0.013 & 0.661 & 0.021 \\
Education Level & 0.042 & 0.815 & 0.337 \\
High School non-completer's Grade & -0.024 & 0.424 & 0.443 \\
Income Level & & 0.379 \\
\hline
\end{tabular}

Unadjusted data. ${ }^{*}$ denotes significant 2-tailed correlation at the alpha $=p=0.05$ level. ${ }^{* *}$ denotes significant 2-tailed correlation at the alpha $=p=0.01$ level.

\section{Discussion}

The objective of this quantitative comparative online survey-based study was to evaluate whether multimodal counseling interventions increase HPV vaccination series non-completers' knowledge of HPV-attributable disease and acceptance of HPV-attributable disease prophylaxis (vaccination), over a control 14-sentence counseling intervention. Given individuality, it is plausible that different counseling interventions will be necessary to reach different people. Different counseling interventions may have different efficacy. Counseling interventions can increase disease process and vaccination knowledge and acceptance by 9.2 to 15 percentage-points [23,33,34]. However, evidence-based practice and economical resource use require case-by-case counseling intervention outcomes evaluations. Therefore, this head-to-head study design evaluated three counseling interventions with a control standard of care counseling intervention. An effective counseling intervention would simultaneously increase HPV knowledge, and HPV vaccination knowledge and acceptance. Effective counseling intervention use could help raise the U.S.' female HPV vaccination rate from $32 \%$ to an achievable, beneficial, potentially herd immunity sustaining $80 \%$.

This study found that compared to the control group, all experimental groups showed a greater increase in HPV-attributable disease and HPV vaccination knowledge, $p=0.038$. The PHEH intervention, and the combined audiovisual and PHEH intervention, raised knowledge of HPV-attributable EGW, $p<0.001$ (Table 5). The combined audiovisual and PHEH intervention raised knowledge of HPV vaccination purpose, $p=0.02$ (Table 5). In a primarily Caucasian or Hispanic public health and private pediatric clinic population preintervention parental knowledge that HPV is causative of EGW may range from 16.43 to $36.25 \%$ respectively [19].

In this study, preintervention knowledge that EGW is an HPV-attributable disease was $44.82 \%$, and of HPV vaccination purpose $41.57 \%$ (Table 4 ). Thus, this study population's preintervention knowledge of HPV-attributable EGW (Table 4) is comparable to that of the aforementioned private pediatric clinic population [19]. However, in both instances, preintervention knowledge was noticeably less than that found among community outreach participants in north central Florida, $74.2 \%$, when asked if HPV causes EGW and cervical cancer [35]. Similarly, 74.3\% of medical students at a midwestern U.S. medical school were aware that HPV vaccination protects against EGW, and 91.1\% were aware that HPV vaccination protects against cervical cancer, both of which represent higher background HPV knowledge than evident in this study's population [18].

The combined PHEH and audiovisual achieved increased HPV vaccination acceptance for seven items, $p<0.001$ to $p=0.023$ (Table 6). The audiovisual intervention achieved increased HPV vaccination acceptance for six items, $p<0.001$ to $p=0.006$ (Table 6). Parents were more likely to accept offers of HPV vaccination for a child than were childless young adults for themselves (68.2\% and $52.9 \%)$. 
Particularly, parents of more sons than daughters were more likely to accept HPV vaccination. While previous investigators excluded fathers and young male adults from their studies, or had low inclusion of fathers, such as $9 \%$ of the sample, in this study fathers and young male adults were $18 \%$ and $21 \%$ respectively of the sample $[24,28,36,37]$. The inclusion of $39 \%$ male participants may have played into the finding that parents of sons retained the most information about HPV.

The finding that generational status remote from an immigration event is associated with increased knowledge and acceptance of HPV is contrary to Bair et al.'s finding that temporal proximity to an immigration event increased the likelihood to accept vaccination [38]. Yet, these findings are consistent with the literature on older adults and health promotion. Earlier studies found older adults were more likely to participate in health promoting behaviors than were younger adults $[39,40]$. The association between increased likelihood to accept HPV vaccination and generational status remote from an immigration event is consistent with foreign-born persons living in the U.S. having lower HPV vaccination initiation rates [41].

The findings are both statistically and clinically significant. Clinically, the findings suggest that EGW prevention may motivate HPV vaccination acceptance, and that older parents are more accepting of HPV vaccination than are childless young adults. Parents of male children retained the most knowledge information about HPV vaccination. Given that less intervention is needed to move a person from contemplation to action, than from pre-contemplation to action, participating parents of male children may have been in a contemplative state about HPV, whereas young adults and parents of daughters could have been pre-contemplative [42]. Additionally, as proportionately more parents than childless young adults were initially accepting of HPV vaccination, adults overall may be more likely to be contemplative towards HPV vaccination than childless young adults. For different age groups, different knowledge and acceptance factors, equivalent to pros and cons of vaccination can facilitate a movement to action [42]. Contemplative male participants are consistent with Patel et al., who found $57.9 \%$ of males to be contemplative, but inconsistent with Perez et al., who found at least $77.9 \%$ of parents of sons to be pre-contemplative of male HPV vaccination $[43,44]$. Nonetheless, knowledge and awareness increasing educational counseling interventions are targeted for precontemplation and contemplation stages of behavioral change, making parents and young male adults the best targets for the multimodal counseling interventions used in this study [45].

Targeted counseling for HPV vaccination acceptance has demonstrated ability to increase HPV vaccination acceptability $[24,26,33,35]$. Gain-framed counseling can convince mothers of sons to consider HPV vaccination [46]. Previous investigators had found cervical cancer prevention was a greater motivator for HPV vaccination acceptance than prevention of a sexually transmitted infection [47]. Yet, this study found that EGW, a visible manifestation of an HPV-attributable STI was the most easily communicated HPV-attributed disease. Therefore, clinicians and health promotion initiatives could target households with male children and older parents for HPV vaccination promotion. Clinically, health care providers should realize young adults, households with more female than male children, and persons associated with a proximate American immigration event who have yet to accept HPV vaccination may be pre-contemplative regarding HPV vaccination. In that case, more effort will be needed to make significant gains in HPV and HPV vaccination knowledge and acceptance. Well-designed handouts can be as effective, or more effective than an audiovisual presentation to help to shift stage of change towards contemplation, potentially reducing counseling costs.

There were several limitations to this study. The composite 25-item demographics questionnaire combined with a repeated 49-item survey instrument could have been excessively long $[23,24,36,48]$. Long surveys may incur diminishing returns with subject fatigue contributing to satisficing behavior and poorer quality responses [49]. Despite the survey's length potentially important questions such as sexual orientation and unmarried persons' intimate relationship status, which affects perceived HPV vaccination need were omitted $[9,50]$. The power to detect differences or adequately describe the target population was reduced by the small sampling of non-Hispanic mixed race, non-Hispanic 
other, and Hispanic other groups, a smaller proportion of Medicaid participants in the audiovisual intervention Group 1, and of vaccination refusers in the Control group.

Moreover, this consumer-based online study population is different from random-dial telephone HPV surveys populations, and college-student or other populations completing online surveys. Selection or response bias occurring with choosing which email to respond to may be different from that occurring when choosing to answer a telephone call. As response, not invitation tracking was used, the rates of invitations per respondent and per included respondent are unknown. Different self-selected populations may have different underlying interest in and knowledge of the topic being surveyed $[18,35]$. Contrary to the literature, neither morality nor religiosity affected HPV vaccination acceptance $[26,27,51]$. Of course, this finding should be interpreted cautiously due to the sparse representation of several religious categories. Unlike Curtis et al., neither health care provider recommendation, income, residence location, the setting in which vaccines are received, nor race significantly affected HPV vaccination acceptance [52]. Also, contrary to the literature, education did not affect HPV vaccine acceptability $[41,45,52,53]$. This consumer-based online study is further limited by the lack of provider- or pharmacy-verified vaccination histories. Participant provided HPV-vaccination status could reflect recall and social desirability biases [45].

The audiovisual choice may have not been as well received as the PHEH, reflected in greater response to the latter than the former. A combination of survey length and audiovisual choice may account for the combined audiovisual and PHEH Group 3 not standing out from the PHEH Group 2 as the most effective intervention. Future studies could be conducted with a larger proportion of over 40-years old; non-Hispanic mixed race, non-Hispanic other, and Hispanic other racial or ethnic groups to improve external generalization. A separate study evaluating audiovisual presentations to determine the most effective audiovisual could improve HPV vaccination counseling. Given a potential $23 \%$ cost differential in using electronic instead of print counseling materials, increased comparative audiovisual effectiveness is essential for audiovisual counseling use [25].

\section{Conclusions}

The objective of this quantitative comparative online study was to evaluate whether multimodal counseling interventions increase HPV vaccination series non-completers' knowledge of HPV-attributable disease and acceptance of HPV-attributable disease prophylaxis (vaccination), over a control 14-sentence counseling intervention. The selected consumer-based online survey population has different characteristics than a random-dialed telephone or college-based online survey population. The results showed that some disease and vaccination-specific information could be successfully communicated in the online format yielding changed perceptions. Foremost, that HPV causes EGW, and that HPV vaccination prevents HPV-attributable diseases and their sequelae were better conveyed by the combined audiovisual presentation and PHEH than the control 14-sentence counseling intervention alone.

Supplementary Materials: The following are available online at www.mdpi.com/2227-9032/5/4/86/s1. Questionnaire S1: Demographic Questionnaire, Questionnaire S2: Young adult HPV Knowledge and Acceptance survey, Questionnaire S3: Parent HPV Knowledge and Acceptance survey, Intervention S1: 14-sentence informational brief, Intervention S2: Public health education handout, Permission S1: A. T. Still University Institutional Review Board, Permission S2: Consent to use the 14-sentence informational brief, Permission S3: Permission to use the audiovisual intervention, Permission S4: Permission to use the public health education handout, Figure S1: Participant demographics: Age by group, Figure S2: Participant demographics: Biologic sex by group, Figure S3: Participant demographics: Children's biologic sex by group, Figure S4: Participant demographics: Race/ethnicity by group.

Acknowledgments: Funding: This is an unfunded work. Presentation at Meetings: A poster of this work was presented at the American College of Obstetricians and Gynecologists Annual Clinical and Scientific Meeting, Washington DC, on 15 May 2016. An oral presentation of this work was given at the 2nd International Congress on Contemporary Issues in Women Cancers and Gynecologic Oncology, London, England, on 29 August 2017. Source of the work: The quantitative portion of the corresponding author's applied research project for the Doctor of Health Science degree, submitted to A. T. Still University. 
Author Contributions: O.N. and H.S. conceived and designed the study; O.N. contracted Survey Monkey to host the survey; O.N. cleaned and coded the data, retrieved and analyzed the literature; O.N., H.S., and C.B. analyzed and interpreted the data; O.N. wrote the paper; O.N., H.S., and C.B. critically revised the prepublication drafts for important intellectual content; O.N., H.S., and C.B. approved the final version for publication.

Conflicts of Interest: C.B. and H.S. declare no conflict of interest. O.N. owns less than $\$ 5000$ common stock outside of mutual funds in both GlaxoSmithKline and Merck.

\section{References}

1. Centers for Disease Control and Prevention. HPV and Cancer. How Many Cancers Are Linked with HPV Each Year? Available online: http:/ / www.cdc.gov/cancer/hpv/statistics/cases.htm (accessed on 23 June 2014).

2. Williams, W.W.; Lu, P.J.; O’Halloran, A.; Kim, D.K.; Grohskopf, L.A.; Pilishvili, T.; Skoff, T.H.; Nelson, N.P.; Harpaz, R.; Markowitz, L.E.; et al. Surveillance of vaccination coverage among adult populations—United States, 2015. MMWR 2017, 66, 1-28. [CrossRef] [PubMed]

3. Giuliano, A.R.; Lu, B.; Nielson, C.M.; Flores, R.; Papenfuss, M.R.; Lee, J.H.; Abrahamsen, M.; Harris, R.B. Age-specific prevalence, incidence, and duration of human papillomavirus infections in a cohort of 290 US men. JID 2008, 198, 827-835. [CrossRef] [PubMed]

4. Forman, D.; de Martel, C.; Lacey, C.J.; Soerjomataram, I.; Lortet-Tieulent, J.; Bruni, L.; Vignat, J.; Ferlay, J.; Bray, F.; Plummer, M.; et al. Global burden of human papillomavirus and related diseases. Vaccine 2012, 30, F12-F23. [CrossRef] [PubMed]

5. Yanofsky, V.R.; Patel, R.V.; Goldenberg, G. Genital warts. A comprehensive review. J. Clin. Aesthet. Dermatol. 2012, 5, 25-36. [PubMed]

6. Armstrong, L.R.; Preston, E.J.D.; Reichert, M.; Phillips, D.L.; Nisenbaum, R.; Todd, N.W.; Jacobs, I.N.; Inglis, A.F.; Manning, S.C.; Reeves, W.C. Incidence and prevalence of recurrent respiratory papillomatosis among children in Atlanta and Seattle. Clin. Infect. Dis. 2000, 31, 107-109. [CrossRef] [PubMed]

7. Chirillă, M.; Bolboacă, S.D. Clinical efficiency of quadrivalent HPV (types 6/11/16/18) vaccine in patients with recurrent respiratory papillomatosis. Eur. Arch. Otorhinolaryngol. 2013. [CrossRef] [PubMed]

8. Giuliano, A.R.; Harris, R.; Sedjo, R.L.; Baldwin, S.; Roe, D.; Papenfuss, M.R.; Abrahamsen, M.; Inserra, P.; Olvera, S.; Hatch, K. Incidence, prevalence, and clearance of type-specific human papillomavirus infections: The young women's health study. JID 2002, 186, 462-469. [CrossRef] [PubMed]

9. Charlton, B.M.; Reisner, S.L.; Agénor, M.; Gordon, A.R.; Sarda, V.; Austin, S.B. Sexual orientation disparities in human papillomavirus vaccination in a longitudinal cohort of U.S. males and females. LGBT Health 2017, 4, 202-209. [CrossRef] [PubMed]

10. Raymakers, A.J.; Sadatsafavi, M.; Marra, F.; Marra, C.A. Economic and humanistic burden of external genital warts. Pharmacoeconomics 2012, 30, 1-16. [CrossRef] [PubMed]

11. Van de Velde, N.; Boily, M.C.; Drolet, M.; Franco, E.L.; Mayrand, M.H.; Kliewer, E.V.; Kliewer, E.V.; Coutlée, F.; Laprise, J.F.; Malagón, T.; et al. Population-level impact of the bivalent, quadrivalent, and nonavalent human papillomavirus vaccines: A model-based analysis. J. Natl. Cancer Inst. 2012, 104, 1712-1723. [CrossRef] [PubMed]

12. Schobert, D.; Remy, V.; Schoeffski, O. Cost-effectiveness of vaccination with a quadrivalent HPV vaccine in Germany using a dynamic transmission model. Health Econ. Rev. 2012, 2, 19. [CrossRef] [PubMed]

13. Héquet, D.; Rouzier, R. Determinants of geographic inequalities in HPV vaccination in the most populated region of France. PLOS ONE 2017, 12, e0172906. [CrossRef] [PubMed]

14. Fregnani, J.H.; Carvalho, A.L.; Eluf-Neto, J.; Ribeiro, K.d.C.B.; Kuil, L.d.M.; da Silva, T.A.; Rodrigues, S.L.; Mauad, E.C.; Longatto-Filho, A.; Villa, L.L. A school-based human papillomavirus vaccination program in Barretos, Brazil: Final results of a demonstrative study. PLoS ONE 2013, 8, e62647. [CrossRef] [PubMed]

15. Hayashi, Y.; Shimizu, Y.; Netsu, S.; Hanley, S.; Konno, R. High HPV vaccination uptake rates for adolescent girls after regional governmental funding in Shiki City, Japan. Vaccine 2012, 30, 5547-5550. [CrossRef] [PubMed]

16. Zhang, S.K.; Pan, X.F.; Wang, S.M.; Yang, C.X.; Gao, X.H.; Wang, Z.Z.; Li, M.; Ren, Z.F.; Zhao, F.H.; Qiao, Y.L. Perceptions and acceptability of HPV vaccination among parents of young adolescents: A multicenter national survey in China. Vaccine 2013, 31, 3244-3249. [CrossRef] [PubMed] 
17. Perkins, R.B.; Brogly, S.B.; Adams, W.G.; Freund, K.M. Correlates of human papillomavirus vaccination rates in low-income, minority adolescents: A multicenter study. J. Womens Health 2012, 21, 813-820. [CrossRef] [PubMed]

18. Afonso, N.M.; Kavanagh, M.J.; Swanberg, S.M.; Schulte, J.M.; Wunderlich, T.; Lucia, V.C. Will they lead by example? Assessment of vaccination rates and attitudes to human papilloma virus in millennial medical students. BMC Public Health 2017, 17, 35. [CrossRef] [PubMed]

19. Tan, T.Q.; Gerbie, M.V. Perception, awareness, and acceptance of human papillomavirus disease and vaccine among parents of boys aged 9 to 18 years. Clin. Pediatr. 2017, 56, 737-743. [CrossRef] [PubMed]

20. Kish, J.K.; Rolin, A.I.; Zou, Z.; Cucinelli, J.E.; Tatalovich, Z.; Saraiya, M. Prioritizing US cervical cancer prevention with results from a geospatial model. J. Glob. Oncol. 2016, 2, 275-283. [CrossRef] [PubMed]

21. Pot, M.; van Keulen, H.M.; Ruiter, R.A.C.; Eekhout, I.; Mollema, L.; Paulussen, T.W.G.M. Motivational and contextual determinants of HPV-vaccination uptake: A longitudinal study among mothers of girls invited for the HPV-vaccination. Prev. Med. 2017, 100, 41-49. [CrossRef] [PubMed]

22. Lashuay, N.; Tjoa, T.; Zuniga de Nuncio, M.L.; Franklin, M.; Elder, J.; Jones, M. Exposure to immunization media messages among African American parents. Prev. Med. 2000, 31, 522-528. [CrossRef] [PubMed]

23. McPhee, S.J.; Nguyen, T.; Euler, G.L.; Mock, J.; Wong, C.; Lam, T.; Nguyen, W.; Nguyen, S.; Ha, M.Q.H.H.; Do, S.T.; et al. Successful promotion of hepatitis B vaccinations among Vietnamese-American children ages 3 to 18: Results of a controlled trial. Pediatrics 2003, 111, 1278-1288. [CrossRef] [PubMed]

24. Reiter, P.L.; Stubbs, B.; Panozzo, C.A.; Whitesell, D.; Brewer, N.T. HPV and HPV vaccine education intervention: Effects on parents, healthcare staff, and school staff. Cancer Epidemiol. Biomark. Prev. 2011, 20, 2354-2361. [CrossRef] [PubMed]

25. Karanth, S.S.; Lairson, D.R.; Huang, D.; Savas, L.S.; Vernon, S.W.; Fernández, M.E. The cost of implementing two small media interventions to promote HPV vaccination. Prev. Med. 2017, 99, 277-281. [CrossRef] [PubMed]

26. Thomas, T.L.; Strickland, O.; Diclemente, R.; Higgins, M. An opportunity for cancer prevention during preadolescence and adolescence: Stopping human papillomavirus (HPV)-related cancer through HPV vaccination. J. Adolesc. Health 2013, 52, S60-S68. [CrossRef] [PubMed]

27. Constantine, N.A.; Jerman, P. Acceptance of human papillomavirus vaccination among Californian parents of daughters: A representative statewide analysis. J. Adolesc. Health 2007, 40, 108-115. [CrossRef] [PubMed]

28. Morales-Campos, D.Y.; Markham, C.M.; Peskin, M.F.; Fernandez, M.E. Hispanic mothers' and high school girls' perceptions of cervical cancer, human papilloma virus, and the human papilloma virus vaccine. J. Adolesc. Health 2013, 52, S69-S75. [CrossRef] [PubMed]

29. Maynard, A. Why Vaccinate against HPV [DVD]. University of Michigan Risk Science Center, Ann Arbor, MI. Available online: https:/ / www.youtube.com/watch?v=2xnoTXzP0qs (accessed on 8 December 2013).

30. Van Zyl, T.; Wooltorton, E.; MacDonald, N. Patient information about HPV and the HPV vaccine. CMAJ 2007, 177, 462. [CrossRef] [PubMed]

31. McCrum-Gardner, E. Which is the correct statistical test to use? Br. J. Oral Maxillofac. Surg. 2008, 46, 38-41. [CrossRef] [PubMed]

32. Portney, L.G.; Watkins, M.P. Foundations of Clinical Research. Applications to Practice, 3rd ed.; Pearson Education: Upper Saddle River, NJ, USA, 2009.

33. Chang, I.J.; Huang, R.; He, W.; Zhang, S.K.; Wang, S.M.; Zhao, F.H.; Smith, J.S.; Qiao, Y.L. Effect of an educational intervention on HPV knowledge and vaccine attitudes among urban employed women and female undergraduate students in China: A cross-sectional study. BMC Public Health 2013, 13, 916. [CrossRef] [PubMed]

34. Johnson, E.A.; Harwell, T.S.; Donahue, P.M.; Weisner, M.A.; McInerney, M.J.; Holzman, G.S.; Helgerson, S.D. Promoting pneumococcal immunizations among rural Medicare beneficiaries using multiple strategies. J. Rural Health 2003, 19, 506-510. [CrossRef] [PubMed]

35. Roussos-Ross, K.; Foster, L.; Peterson, H.V.; Decesare, J. Do educational seminars for the human papillomavirus vaccine improve attitudes toward the value of vaccination? J. Pediatr. Adolesc. Gynecol. 2017, 30, 456-459. [CrossRef] [PubMed]

36. Donadiki, E.M.; Jiménez-Garcia, R.; Hernāndez-Barrera, V.; Carrasco-Gaarrido, P.; Lōpez de Andrés, A.; Jimez-Trujillo, I.; Velonakis, E.G. Knowledge of the HPV vaccine and its association with vaccine uptake among female higher-education students in Greece. Hum. Vaccines Immunother. 2013, 92, 300-305. [CrossRef] 
37. Gross, M.S.; Tran, C.H.; Sutherland, K.H.; Castagno, J.C.; Amdur, R.J. Pilot study: Can an educational intervention increase human papillomavirus vaccination in female college students? Obstet. Gynecol. 2014, 123, 114S-115S. [CrossRef]

38. Bair, R.M.; Mays, R.M.; Sturm, L.A.; Zimet, G.D. Acceptability of the human papillomavirus vaccine among Latina mothers. J. Pediatr. Adolesc. Gynecol. 2008, 21, 329-334. [CrossRef] [PubMed]

39. Becker, C.M.; Arnold, W. Health promoting behaviors of older Americans versus young and middle aged adults. Educ. Gerontol. 2004, 30, 835-844. [CrossRef]

40. Heidrich, S.M. Health promotion in old age. Annu. Rev. Nurs. Res. 1998, 16, 173-195. [PubMed]

41. De, P.; Budhwani, H. Human papillomavirus (HPV) vaccine initiation in minority Americans. Public Health 2017, 144, 86-91. [CrossRef] [PubMed]

42. Lipschitz, J.M.; Fernandez, A.C.; Larson, H.E.; Blaney, C.L.; Redding, C.A.; Prochaka, J.O.; Paiva, L. Validation of decisional balance and self-efficacy measures for HPV vaccination in college women. Am. J. Health Promot. 2013, 27, 299-307. [CrossRef] [PubMed]

43. Patel, D.A.; Grunzweig, K.A.; Zochowski, M.K.; Dempsey, A.F.; Carlos, R.C.; Dalton, V.K. Human papillomavirus vaccine stages of change among male and female university students: Ready or not? J. Am. Coll. Health 2013, 61, 336-346. [CrossRef] [PubMed]

44. Perez, S.; Shapiro, G.K.; Brown, C.A.; Dube, E.; Ogilvie, G.; Rosberger, Z. “I didn't even know boys could get the vaccine': Parents' reasons for human papillomavirus (HPV) vaccination decision making for their sons. Psycho-Oncology 2015. [CrossRef] [PubMed]

45. Mohammed, K.A.; Vivian, E.; Loux, T.M.; Arnold, L.D. Factors associated with parents' intent to vaccinate adolescents for human papillomavirus: Findings from the 2014 national immunization survey-teen. Prev. Chronic Dis. 2017, 14, 160314. [CrossRef] [PubMed]

46. Gainforth, H.L.; Cao, W.; Latimer-Cheung, A.E. Message framing and parents' intentions to have their children vaccinated against HPV. Public Health Nurs. 2012, 29, 542-552. [CrossRef] [PubMed]

47. Leader, A.E.; Weiner, J.L.; Kelly, B.J.; Hornik, R.C.; Cappella, J.N. Effects of information framing on human papillomavirus vaccination. J. Womens Health 2010, 18, 225-233. [CrossRef] [PubMed]

48. Brawner, B.M.; Baker, J.L.; Voytek, C.D.; Leader, A.; Cashman, R.R.; Silverman, R.; Peter, N.; Buchner, B.J.; Barnes, C.A.; Jemmott, L.S.; et al. The development of a culturally relevant, theoretically driven HPV prevention intervention for urban adolescent females and their parents/guardians. Health Promot. Pract. 2013, 14, 624-636. [CrossRef] [PubMed]

49. Cape, P. Questionnaire Length, Fatigue Effects and Response Quality Revisited. Available online: http:/ / www. websm.org/uploadi/editor/1400241088SSI_QuestionLength_WP.pdf (accessed on 20 September 2017).

50. Thompson, E.L.; Vamos, C.A.; Straub, D.M.; Sappenfield, W.M.; Daley, E.M. “We've Been Together. We Don’t Have It. We're Fine." How Relationship Status Impacts Human Papillomavirus Vaccine Behavior among Young Adult Women. Womens Health Issues 2017, 27, 228-236. [CrossRef] [PubMed]

51. Krakow, M.M.; Jensen, J.D.; Carcioppolo, N.; Weaver, J.; Liu, M.; Guntzviller, L.M. Psychosocial predictors of human papillomavirus vaccination intentions for young women 18 to 26 : Religiosity, morality, promiscuity, and cancer worry. Womens Health Issues 2015, 25, 105-111. [CrossRef] [PubMed]

52. Curtis, C.R.; Dorell, C.; Yankey, D.; Jeyarajah, J.; Chesson, H.; Saraiya, M.; Gold, R.; Dunne, E.F.; Stokley, S. National human papillomavirus vaccination coverage among adolescents aged 13-17 years-National immunization survey-Teen, United States, 2011. [Supplements]. MMWR 2014, 63, 61-70.

53. Brewer, N.T.; Fazekas, K.I. Predictors of HPV vaccine acceptability: Theory-informed, systematic review. Prev. Med. 2007, 45, 107-114. [CrossRef] [PubMed]

(C) 2017 by the authors. Licensee MDPI, Basel, Switzerland. This article is an open access article distributed under the terms and conditions of the Creative Commons Attribution (CC BY) license (http://creativecommons.org/licenses/by/4.0/). 